KaPUScinski.-Ber. deut. Ophthal. Gesellsch., Vol. L, p. 13, 1934.

KNAPP.-Klin. Monatsbl.f. Augenheilk., Vol. CDLI, p. 171, 1907.

Levinsohn.-Arch. f. Augenheilk., Vol. XXXVIII, p. 268, 1899; Arch. of Ophthal., Vol. XXXII, p. 6, 1903

Morton.-Trans. Ophthal. Soc. U.K., Vol. V, p. 142, 1885 ; Ibid., Vol. XIII, p. $282,1893$.

NetTLESHIP.-Trans. Ophthal. Soc. U.K., Vol. IV, p. 165, 1884.

Oeller.-Ophthalmoskopischer Atlas. Wiesbaden, 1899. Plates D.14, D.15 and D.7.

Atlas seltener ophthalmoskopischer Befunde. Wiesbaden, 1905. Plate D.1

Pillat.-Amer. Jl. of Ophthal., Vol. XIII, p. 1, 1930.

Pöllot.-Arch f. Ophthal., Vol. LXXX, p. 379, 1911

RETzE.--Beiträge zur Augenheilk., Bd. V, Heft 47, S. 94, 1901.

Thоmpson.-Trans. Ophthal. Soc. U.K., Vol. XXV, p. 118, 1905 ; Ibid., Vol. XXI, p. 66,1901 .

WEIss.-Klin. Monatsbl.f. Augenheilk., Vol. LII, p. J42, 1914.

Wilmer.-Atlas Fundi Oculi. New York. 1934. : Plate 82.

(2) OTHER REFERENCES.

Ascher.-Ber. deut. Ophthal. Gesellsch., Vol. XLIX, p. 547, 1932 ; Arch.f. Augenheilk., Vol. CVI, p. 585, 1932.

GinsBerg. - Klin. Monatsbl. f. Augenheilk., Vol. XLVI, p. 1, 1908.

GoNIN.-Ann. d'Ocul., Vol. CXXIX, p. 24, 1903.

Sorsby, Avery and Cockayne.-Quart. Jl. Med., N.S. ; Vol. VIII, p. 51, 1939.

STOck.-Klin. Monatsbl.f. Augenheilk., Vol. XLVI, p. 225, 1908.

SUGanuma.-Ibid., Vol. L, p. 178, 1912.

VERHOEFF - Arch. Of Ophthal., Vol. LXII, p. 392, 1931.

Wibaut.-Klin. Monatsbl. f. Augenheilk., Vol. LXXXVII, p. 299, 1931.

\title{
A CASE OF ALEUKAEMIC LYMPHOSIS INVOLVING THE UPPER LIDS. WITH PATHOLOGICAL FINDINGS*
}

BY

\author{
FREDERICK T. TOOKE \\ MONTREAL, CANADA
}

(FROM THE DEPARTMENT OF OPHTHALMOLOGY ROYAL VICTORIA HOSPITAL, MONTREAL, CANADA.)

THE globe and its appendages are occasionally the site of abnormal proliferation of the lymphoid tissues. In very rare cases these occur as local tumour growths, either of benign lymphomatous, or of malignant lymphosarcomatous character. In the vast majority of cases, however, the lesion of this region is merely part of a systemic disease which sooner or later comes to involve more or less of the lymphoid tissue of the body. Consequently, any of the various forms of systemic proliferation of lymphoid tissues may express itself in this region, and hence a great variety

\footnotetext{
${ }^{*}$ Read before the American Ophthalmological Society, San Francisco, June 8,
938 .
} 
of these diseases may be the fundamental cause of the tumour-like growth of the eye. In the past, a great deal of stress has been put upon the differential diagnosis of many of these processes from the standpoint that they were to be looked upon as distinct entities. Now we realise that many of these conditions form a related series which differ only in the character of the proliferative activity. Once this fact is appreciated, it becomes quite evident that we are not so concerned with the sharp separation of the various members of this group of diseases, but rather we are interested in their inter-relationship, and the position which the individual case takes in the whole.

A most interesting case of this character has recently come to our attention. It concerns a male patient, aged 65 years, and weighing 236 pounds, who was admitted to the wards of the Royal Victoria Hospital, Montreal, in January, 1938, owing to progressive swelling of both upper eyelids. He first noticed that the lids were swollen the previous July; but this swelling seemed to subside or to be assisted after the use of astringent drops. He was seen at more frequent intervals during the autumn and his admission dated approximately six months after symptoms had first become manifest.

On admission the right lid was pendulous and relatively immobile. A tumour was present which measured $4 \mathrm{~cm}$. horizontally and $2 \mathrm{~cm}$. vertically. The thickness of the lids measured with calipers at the time of admission, was 6 to $7.5 \mathrm{~mm}$. The skin of the lids was not discoloured and was freely movable over the underlying tumour. The swelling conveyed the impression of consisting of one large soft smooth central mass with a smaller one on either side of it. These masses were freely movable over the tarsal plate. The palpebral fissure was very much constricted and the outer half of the upper lid appeared to overlap the lower lid. The apparent palpebral fissure measured $20 \mathrm{~mm}$. $\times 3 \mathrm{~mm}$. (Fig. 1).

The lid was everted with considerable difficulty. 'The palpebral conjunctiva was thick, lustreless, of a pinkish-grey colour and resembled somewhat sodden blotting paper. It was particularly thick and appeared in rolls in the neighbourhood of the accessory lacrimal gland. The tarsal plate was not involved and the neoplasm did not seem to have materially infiltrated or penetrated into the underlying sub-conjunctival areolar tissue. The swelling of the left lid presented practically identical features. It entirely overlapped the lower lid, the only aperture being formed by the forward thrust of the upper lid by the pressure of the swelling against the eye-ball. The tumour measured $4.5 \mathrm{~cm} . \times 2.3 \mathrm{~cm}$., while it registered 5 to $6.5 \mathrm{~mm}$. in thickness. In each case, with the exception of a moderate degree of chemosis about the accessory 
lacrimal glands, the globes appeared normal; the corneae were clear, the anterior chambers were of normal depth, the pupils were regular and active and the fundi were normal. Tension was not raised and vision with correction was $6 / 6$ with each eye. For purposes of comparison, the lids of a patient of practically the same body weight, measured $2.7 \mathrm{~mm}$. in thickness.

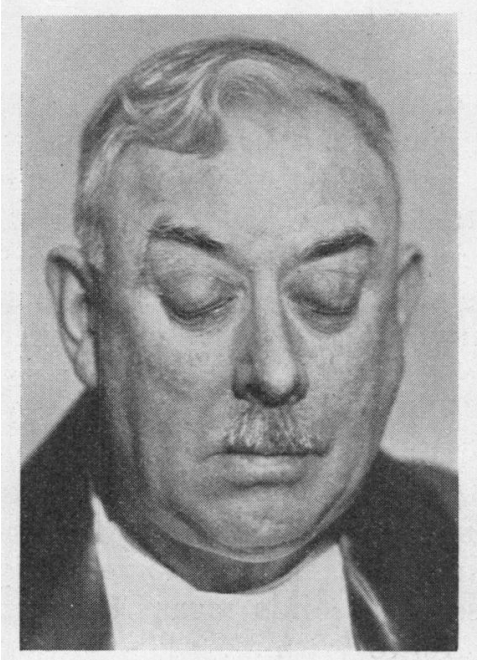

FIG. 1. January 8, 1938.

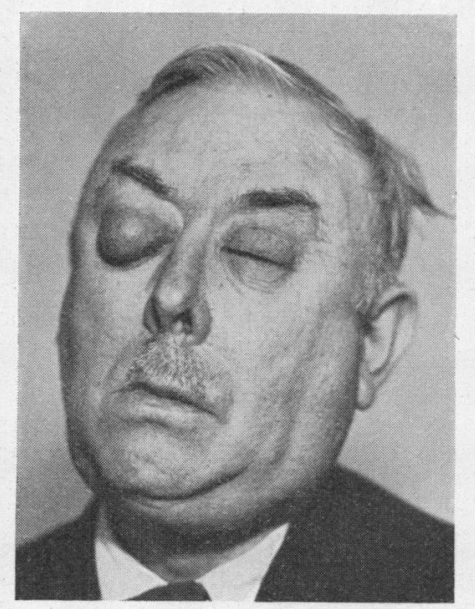

FIG. 3. April 28, 1938.

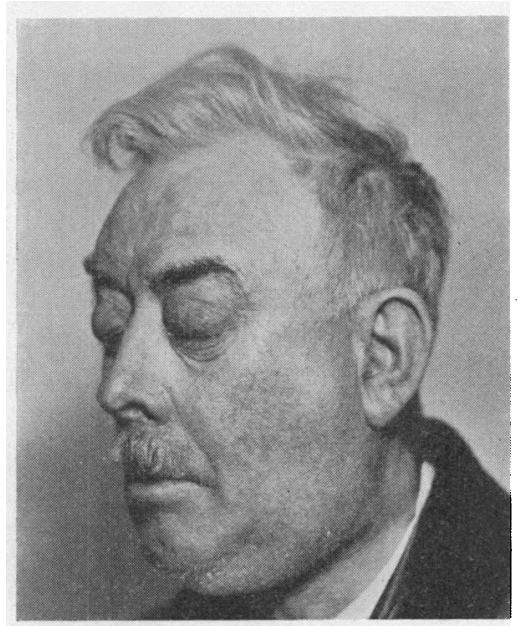

FIG. 2. April 19, 1938.

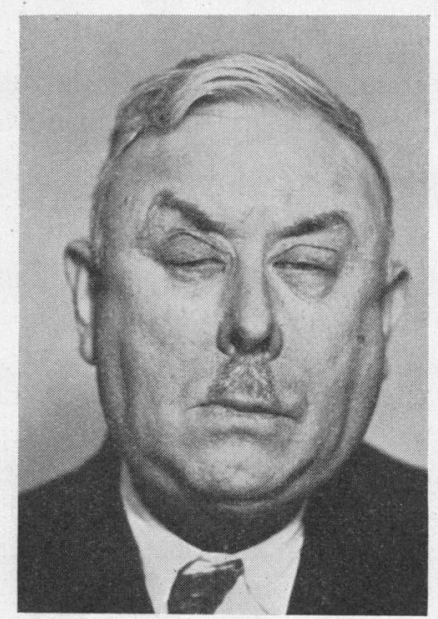

FIG. 4. May 25, 1938. 
Glandular System.-There was a uniform adenopathy. The preauricular and the postauricular glands, the submaxillaries, submental, the anterior and posterior cervical glands were all enlarged, the preauricular being larger than the others. The

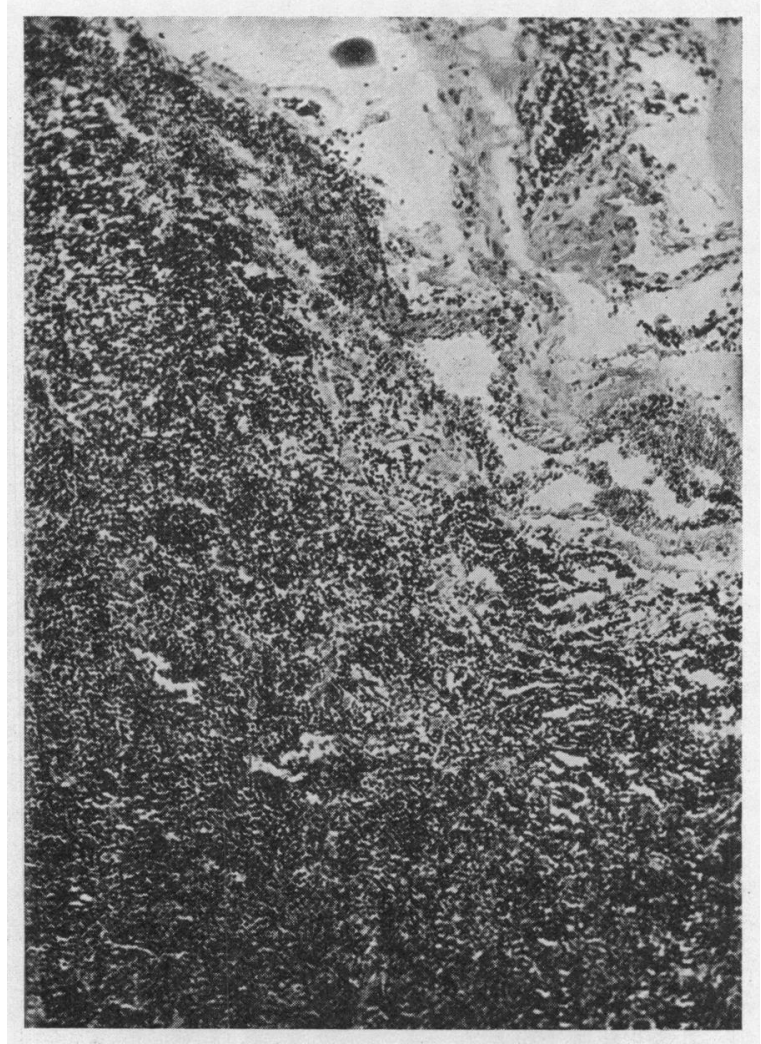

FIG. 5.

Paraffin section of tissue of left upper lid (low power). Densely packed lymphoid cells, medium in size.

axillary, the inguinal, and the epitrochlear glands were also enlarged. The heart was slightly hypertrophied to the left. B.P. registered $142 / 84$. The respiratory system was normal.

Abdomen.-The patient was very obese; there was no tenderness or rigidity and no organs or masses were palpable owing to the adiposity. The hernial orifices (inguinal) were slightly enlarged.

Central Nervous System.-The superficial and deep reflexes were equal and active. Babinski's sign was negative; the cranial nerves were intact. 
A film of the chest showed marked enlargement and increased density involving both lung roots. This enlargement of the roots of the lung might be due to hypertrophied glands adjacent to the hila and in the region of the tracheal bifurcation.

A biopsy was done on the left upper lid. A vertical section was made through the conjunctiva of the everted lid and through

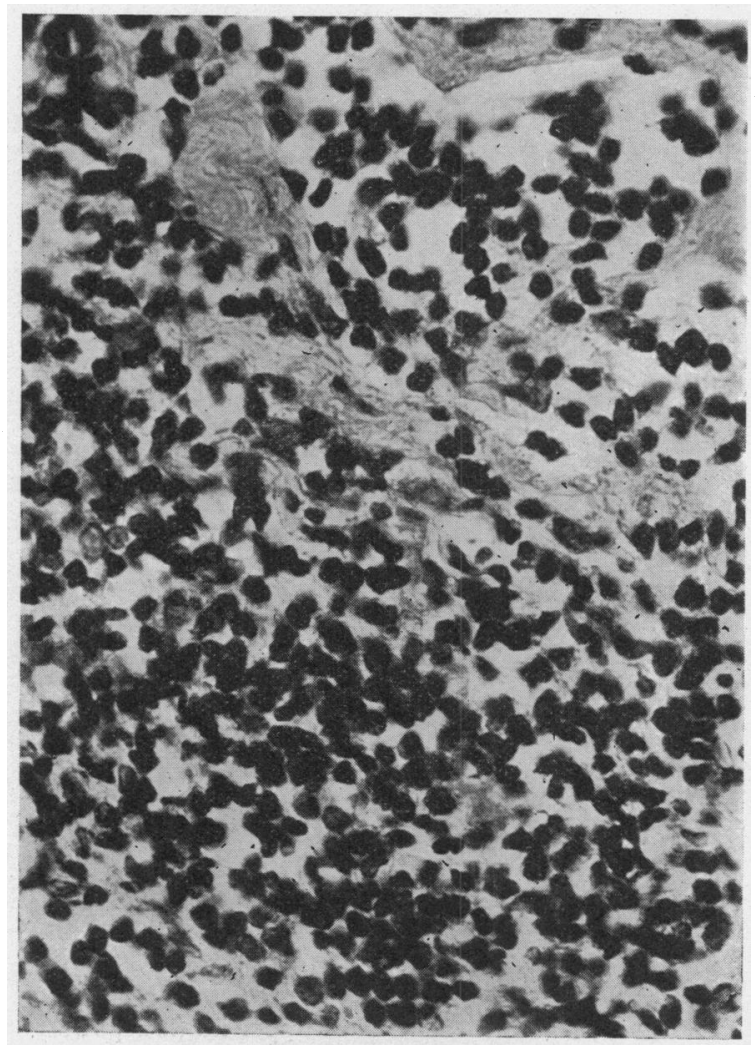

FIG. 6.

Paraffin section of tissue of left upper lid (high power). Densely packed lymphoid cells, of medium size, exhibiting occasional mitotic figures. Corresponds to elements encountered in section through lymph gland.

which the sub-conjunctival tissue protruded. This tissue was similar in colour and appearance to the centre of a boiled potato and had the consistency of cream cheese on cutting. The edges of the conjunctival tissue were brought together with some difficulty owing to stretching brought about by the tumour. No complication followed convalescence. 
A biopsy of one of the right posterior cervical glands was done. The tissue removed was larger than a peanut and very soft in consistency. One portion of the capsule was nicked and a thick cheesy-like material escaped, similar to that noted in the lid incision.

Paraffin sections of the lid showed densely packed lymphoid cells, rather medium in size, exhibiting occasional mitotic figures and corresponding to the elements met with in the lymph glands described below. (Figs. 5 and 6.) Such a proliferation would be classed amongst the more immature types of lymphatic

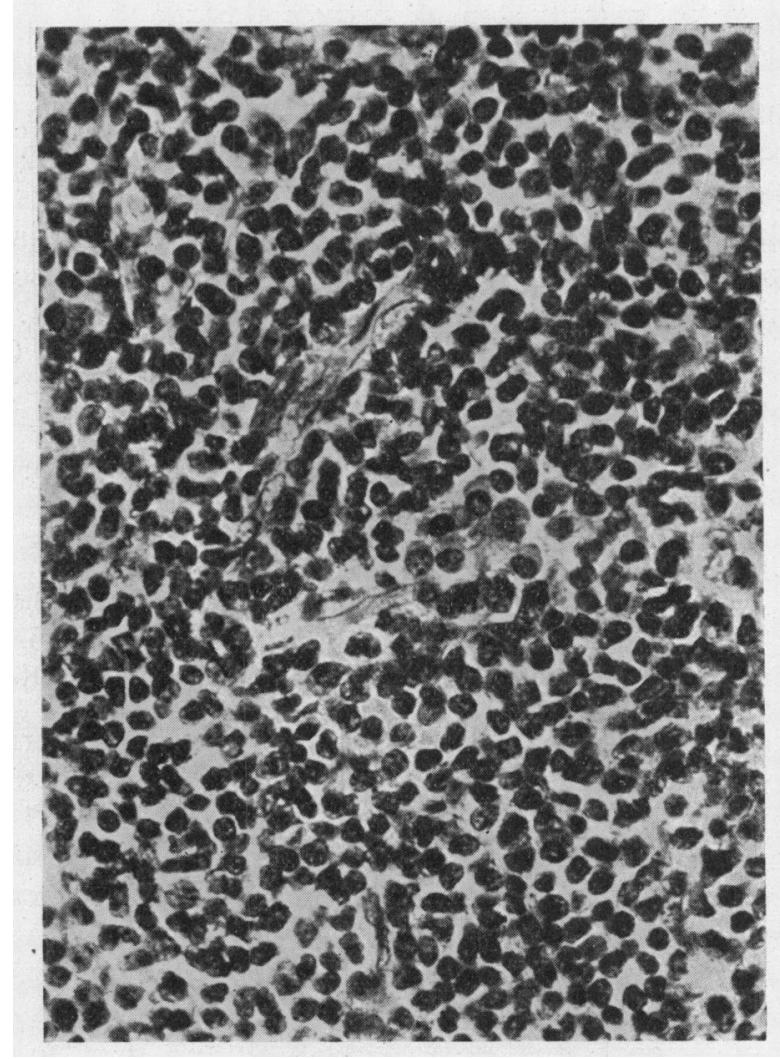

FIG. 7.

Paraffin section of tissue from posterior cervical lymph gland (high power). Loss of normal structure due to intense proliferation of closely packed, small, round lymphoid cells. The cells are quite uniform, a tritle angular in some areas, with a suggestion of clinging to the reticulum. 
leukaemia with appreciation that it borders on a lymphosarcomatosis. The findings are very similar though somewhat more immature to that frequently described under the term "lymphatic leukaemia cutis."

Paraffin sections of the lymph gland showed a loss of normal structure due to an intense proliferation of closely packed, quite small, round lymphoid cells. The cells were quite uniform, they appeared to be a trifle angular in some areas, with a suggestion of clinging to the reticulum. The picture presented here again corresponds to that found on the borderline between a lymphatic leukaemia and a relatively mature form of lymphosarcomatosis. We were inclined from the general appearance to classify it amongst the rather immature forms of lymphatic leukaemia. (Fig. 7.)

Morphological blood examination-January 10, 1938.

R.b.c. :-2,700,000. W.b.c. :-5,600. Haemo.: -57 per cent. (8.7 $\mathrm{gm} / 100$ c.c.). C.I. :-1.06.

Red Blood Cells.-Stain well. Slight anisocytosis and no poikilocytosis. No polychromatophilia, punctate basophilia or nucleated reds. Reticulated reds :- - less than 1 per cent. filament. Index of haemolysis:-460. Fragility:-normal. Corpuscle volume :--28 per cent. Average corpuscle volume :-104 cubic microns. Haemoglobin concentration :-97. Majority corpuscle diameter : -7.8 microns. Sedimentation velocity :- (corrected for C.V.) $=25$, moderately increased.

White Blood Cells.-

Polys. (Segment rod) Myel. Eosin. Mast. Monos. Lymphs.

$\begin{array}{lccccccc}25 \cdot 5 & (22 \cdot 25 & 2 \cdot 7) & 4 & 0 & .75 & 5 \cdot 5 & 65 \cdot 25 \text { per cent. } \\ 1,428 & (1,264 & 154) & 56 & 0 & 42 & 308 & 3,766 \text { per } \mathrm{cmm} .\end{array}$

There is a reduction in polys. with some immature forms. The lymphocytes are increased due to the presence of immature lymphoblastic elements.

Platelets :-100,000. Usual size and shape.

Bleeding time:-Not appreciably prolonged. Rumpel-Leeds : negative.

Coagulation:-fibrin congealing with calcium retraction 5 min. 9 min. 7 min. present.

Plasma.-Yellow with faint greenish tinge. Refraction :- $\tilde{i} 1$.

Van den Bergh :-Direct, prompt, negative; delayed, faintly positive indirect :- less than 0.3 units.

Conclusions.-The picture shows a quite marked anaemia with tendency for the cells to be somewhat larger than normal, and poor regenerative ability. There is a moderately increased sedimentation velocity. The white blood cells show deficiency in the number of the myeloid elements, with some immature forms. The 
lymphocytes are increased, and this increase appears to be due to the presence of occasional lymphoblastic cells, corresponding to those met with in the lymph glands.

The blood picture is neither typical of a lymphatic leukaemia, nor lymphosarcomatosis, so we are inclined to believe that the condition represented here probably lies on the borderline between these two diseases. That such an intermediate type might well occur is understood by the intimate relationship between these two conditions and that the latter is simply of more immature undifferentiated nature. For the purpose of classification it is probably best considered an aleukaemic lymphosis, i.e., an aleukaemic form of lymphatic leukaemia.

Morphological blood examination-January 27, 1938.

R.b.c. :-2,500,000. W'b.c. :-5,000. Haemo.:-51 per cent. (7.9 gm/100 c.c.). C.I.:-1.02.

Conclusions.- The blood picture is essentially the same as at previous examination (January 10, 1938). There is a slight general change for the worse.

Morphological blood examination-May 19, 1938.

R.b.c. :-1,700,000. W.b.c. :-8,000. Haemo. :-34 per cent. (5.3 gm/100 c.c.). C.I :-1.

Conclusions. - The general character of the blood picture met with at the last examination (January 27, 1938), is maintained. There is a general change for the worse, indicating in all probability a more extensive involvement of the haemopoietic system.

When treatment was inaugurated by $\mathrm{X}$-rays each lid registered $13 \mathrm{~mm}$. of swelling, the hyperplasia having very manifestly increased through delay. On April 19,500 R. units filtered through $3 \mathrm{~mm}$. Al. to the left eyelid, the cornea being protected by lead plate. On April 20,250 R. units were applied to the same lid (Fig. 2). An April 27, 350 R. units were applied to the right eyelid, and on April 28, $400 \mathrm{R}$. units were applied to the same lid (Fig. 3). The total dosage to each lid was $750 \mathrm{R}$ units. On May 25, after practically one month's delay, X-ray treatment was resumed and $125 \mathrm{R}$. units were applied to each lid. (To date-1,000 R. units have been applied to both lids.)

The effect of this treatment has been most spectacular in that the growths have apparently melted away (Fig. 4). The patient can now raise his lids and find his way about with ease, and the thickness of each lid registers $3 \mathrm{~mm}$. Such improvement, however, unfortunately must only be regarded as local as the patient's general condition is definitely worse since he has come under our observation. The glands, particularly about the face, are distinctly more enlarged. His weight has decreased by nearly 50 pounds, which now affords one an opportunity of demonstrating the spleen to be rounded at its edge and to exend $8 \mathrm{~cm}$. beyond 
the costal margin, while the liver is hypertrophied and nodular and also extends $8 \mathrm{~cm}$., beyond the rib margin. His breathing on the slightest exertion is laboured manifesting an additional hyperplasia of the mediastinal glands, while his haemoglobin has fallen from 57 per cent. to 34 per cent.

\section{Discussion}

If one turns to the ophthalmological literature on this subject, one is at once impressed by the fact that there exists considerable confusion because of a lack of uniformity in the terminology employed. Most authors emphasise the difficulties of precise diagnosis and classification.

Duke-Elder, in his textbook of Ophthalmology, Vol. 2, p. 1,796, 1938 , places lymphomata or lymphoblastomata under tumours of the haemopoietic system. He states at the outset that a differentiation of tumours arising from the lymphocyte-forming tissues is difficult, and in the conjunctiva the difficulty is increased by their great variety. They may be divided into two classes depending on whether they are simple or malignant.

1. Simple lymphomata represent a variety of opinions : pathologically they manifest a marked hyperplasia of lymphoid tissue. Axenfeld (Arch.f. Ophthal., Vol. XXXVII, p. 4, 102, 1891), and Meller (Ibid., 62, 130, 1906), consider that they are always associated with some disease of the haemopoietic system; while other authorities are equally convinced that they occur without any constitutional disease-Coats (Ann. of Ophthal., Vol. XLIV, p. $235,1915)$. No adequate explanation has been brought forward to account for the appearance of the latter class. It has been suggested that they may arise from foetal remains in the orbitBoerma (Arch. f. Ophthal., Vol. IV., p. 219, 1894); Goldzieher (Ibid., Vol. XLVII, p. 71, 1907).

A. Lymphomata occur with these diseases associated with a hyperplasia or metaplasia of the lymphoid and blood forming tissues and are frequently noted with enlargement of the lymph gland, spleen, and liver, with changes in the bone marrow. They may be manifest in cases of lymphatic leukaemia which they resemble in their occurrence and histologically the multiple tumour-like nodes seen in the skin in this disease-lymphatic leukaemia cutis. Less frequently they may be met with in Hodgkin's disease, in Banti's disease, in pseudo-leukaemia and other haemopoietic disturbances. Unlike the case under consideration they are small, hard, red fleshy tumours, painless and of slow growth. They may invade the palpebral and bulbar conjunctiva, the plica and limbus, and may also extend to the cornea. Note a case recently reported in the Journal of the Canadian 
Medical Association, Vol. XXXVIII, No. 5, p. 47\%, by Aylesworth. Histologically the growth is made up of lymphocytes, the blood vessels being supported by a sparse and delicate connectivetissue framework. They may show a tendency to infiltrate and a differential diagnosis between a benign lymphoma and a malignant sarcoma may constitute a histological puzzle. As Duke-Elder continues to suggest, much truth may be gaineà from the blood picture.

B. Lymphomata occurring without evidence of constitutional disease present the same histological picture and clinical appearance as do those associated with leukaemia. They may be bilateral, symmetrical, and are met with most frequently in middle aged adults. There may be an associated enlargement of the lymph gland. These tumours may be of slow growth. Meyer (Arch. f. Augenheilk, Vol. LXXXIX, p. 156, 1921), has described one case which had persisted for seven years.

2. Lymphosarcomata, according to Duke-Elder, when a definite element of malignancy is evident, are rarely met with. Histologically, as I have attempted to point out, the comparison to a simple lymphoma is close; a mass of small round cells with some larger reticular cells. The tumours are fat and soft, of rapid growth, high local malignancy, with a special tendency to spread by the lymphatics.

R. Kummel (Lubarsch and Heinke Handbuch der spec. Path. Anat., Vol. XI, p. 2, 225), disposes of the subject more briefly. $\mathrm{He}$ concludes that in order to attempt to establish a definite diagnosis a blood picture is essential; even then he considers an exact diagnosis to be frequently a matter of doubt.

It would seem quite apparent, therefore, that in consideration of the lymphoid proliferations of this region, we must recognise that there is first of all a very rare type of either benign or malignant growth which is of purely local character, and is not associated with any generalised systemic disease of the other lymphoid tissues of the body. Nevertheless, by far the majority of the cases, in which lymphoid proliferation occurs in this region, are part and parcel of one of the various haemopoietic diseases, which involve as a rule, sooner or later, the bone marrow, spleen, lymph glands, and even other lymphoid tissues of the body.

For years, and in fact, since the original work of Hodgkin, authors interested in haematology, have been concerned with the identification and separation of these various processes into clear cut disease entities. More recently, however, there has been a definite trend to an appreciation that these various conditions form an inter-related series with no sharp lines of separation, but a gradual grading from one into the other. Waugh* has recently

\footnotetext{
* WAUGH, T. R. - The inter-relation of various systemic haematopoietic processes. Amer. Jl. Med. Sci., Vol. CXCIII, p. 337, 1937.
} 
emphasised this view in an aticle on the inter-relation of various systemic haemopoietic conditions, and from our standpoint it seems most important that we appreciate this trend as it explains the great difficulties which have arisen in the past in the sharp separation of these various conditions, and allows us to approach the subject from the much more natural viewpoint of placing any particular case in its proper position in the series, rather than trying to separate it sharply from other closely related conditions.

As regards treatment: X-rays were first employed by v. Duyse (Arch. d'Ophtal., Vol. XXV, p. 402, 1905), and satisfactory results have been reported by Tiscornia (Rev. Assoc. Med. Argent., XXXVI, 818, 1923)-quoted by Duke-Elder and Speciale-Riccichi (An. di Ottal., Vol. LV, p. 412, 1927). Radium has been used to advantage by Shannon and McAndrews (Amer. Jl. Ophthal., Vol. XV, p. 821, 1932).

Turning to the particular case under discussion here, we find that it consists of one of the rarer, more active types of lymphoid proliferations which lie on the border-line between the more common forms of lymphatic leukaemia and the lymphosarcomatoses.

That this might be the case was first suspected from the character of the tissue removed from the eyelid. It showed a proliferation of lymphoid cells which, while comparatively uniform and closely packed together, were larger and distinctly less differentiated than those met with in the usual type of leukaemia cutis. Biopsy of the lymph gland showed a similar picture.

When the blood examination was first carried out this idea was substantiated again by the findings as there was present in the circulating blood a number of quite immature lymphoblastic elements. The total number of lymphoid cells was increased, but there was not the very high figures met with in the usual lymphatic leukaemia. This case, therefore, is one of a systemic lymphoid proliferation, which apparently from the progressive changes in the blood picture has involved the bone marrow, spleen, and lymph glands of the patient, as well as in an unusual manner, the eyelids. The proliferation is of a comparatively active form, and falls in its intensity and character between that met with in lymphatic leukaemia and that in lymphosarcomatosis. For this reason it is best classified as a leukaemic form of lymphosis, with unusual involvement of the eyelids and with an activity of cell proliferation bordering on the lymphosarcomatoses. 